\title{
A NEW APPROACH FOR SPLIT RENAL FUNCTION EVALUATION OF GLOMERULAR FILTRATION RATE, PERFUSION AND PLASMA FLOW BY NUMERICAL ANALYSIS OF 3D MSCT-BASED MODELS
}

\author{
Alyaev Yu.G. ', Khokhlachev S.B. ${ }^{2}$, Fiev D.N. ${ }^{1}$, Borisov V.V. ${ }^{\text {, }}$ \\ Proskura A.V.' , lurova M.V.'
}

I

ntroduction. Instrumental methods of examination may alter the course of treatment and patients' management. Several studies have shown that interobserver variability in values obtained with renal scintigraphy (RS) can be as high as $10 \%$, however, RS remains the standard investigation for the assessment of split renal function.

Objective. This paper aims to present how numerical analysis of abdominal MSCT results can be used to evaluate split renal function.

Materials and methods. A prospective study was launched in a Research Institute for Uronephrology and Reproductive Health from November, 2015 to May, 2017. 88 patients were enrolled into the study ( 2 with hydronephrosis, 10 with hypertensive kidney disease, 5 with stone kidney disease, 2 with kidney anomalies, 69 with renal tumors). Comparison made between renal scintigraphy data and 3D MSCT-based models. Results. CT-based methods for the calculation of split renal function with 3D-models showed correlation with renal scintigraphy $(p<0.004)$.

Conclusion. A new approach for split kidney function assessment based on contrast-enhanced CT with 3D-models and mathematical analysis allows for both acquiring detailed data on clinical anatomy and evaluation of renal function to promote preoperative decision-making. It showed strong correlation with no significant difference in comparison with RS in terms of glomerular filtration rate, perfusion and plasma flow.

Keywords: 3D-models, MSCT, scintigraphy, split renal function assessment.

Corresponding author: Iurova M.V., iurovamv@gmail.com.

For citation: Alyaev Yu.G., Khokhlachev S.B., Fiev D.N., Borisov V.V., Proskura A.V., Iurova M.V. A new approach for split renal function evaluation of glomerular filtration rate, perfusion and plasma flow by numerical analysis of 3D MSCT-based models. REJR 2018; 8(2):105-109. DOI:10.21569/2222-7415-2018-8-2-105-109.

Received: $\quad 23.03 .2018 \quad$ Accepted: 16.05 .2018

\section{НОВЫЙ МЕТОА РАСЧЕТА КАУБОЧКОВОЙ ФИАЬТРАЦИИ, ПЕРФУЗИИ И ПЛАЗМАТОКА НА ОСНОВАНИИ ЧИСАЕННОГО АНААИЗА ТРЕХМЕРНЫХ ААННЫХ, ПОАУЧЕННЫХ ПРИ МСКТ}

\author{
Аляев Ю.Г.' ', Хохлачев С.Б.2, Фиев А.Н.1 , Борисов В.В. ${ }^{1}$, \\ Проскура А.В.', Юрова М.В. ${ }^{3}$
}

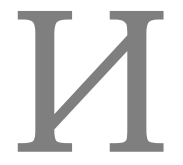

нструментальные методы исследования оказывают существенное влияние на выбор оптимального мечения. В ряде исследований было показано, что погрешность данных, полученных методом реносцинтиграфии (РС) при расчёте скорости клубочковой фильтрации достигает 10\%. Несмотря на это, реносцинтиграфия остаётся "золотым" стандартом исследования раздельной функции почек.

Цель исследования. В статье изцожен инновационный метод расчёта пара-
1 - I.M. Sechenov First Moscow State Medical University (Sechenov University), 2 - Central Scientific and Research Institute for Dentistry. Moscow, Russia.
1 - НИИ Уронефрологии и Репродуктивного Здоровья Человека, ФГАОУ ВО Первый МГМУ им. И.М. Сеченова Минздрава России (Сеченовский университет).

2 - Центральный Научный и Исследовательский Институт Стоматологии. 3 - ФГАОУ ВО Первый МГМУ им. И.М. Сеченова Минздрава России (Сеченовский университет).

Москва, Россия. 
метров, необходимых дмя интерпретации функциональной сохранности в интересующей единице паренхимы.

Материалы и методы. Исследование было выполнено на базе НИИ Уронефромогии и Репродуктивного Здоровья Чемовека с ноября 2015 г. по май 2017 г. Бым проведён сравнительный анализ данных реносцинтиграфии и трехмерных моделей MCKT с контрастированием 88 пациентов с разцичными патологиями почек (мочекаменная болезнь $(\mathrm{n}=5)$, аномалии развития $(\mathrm{n}=2)$, гидронефроз $(\mathrm{n}=10)$, вторично сморщенная почка ( $\mathrm{n}=10)$, опухомь $(\mathrm{n}=69))$.

Результаты. Новый метод исследования сопоставим в точности и информативности с рутинно используемой реносцинтиграфией $(\mathrm{p}<0.004)$.

Заключение. Новый метод исследования раздемьной функции почек обеспечивает специалиста не только точным математическим расчётом СКФ, перфузии и плазмооттока, но и информативной 3D-модемью зоны потенциального мечебного воздействия.

Ключевые слова: 3D-модемь, MCKT, раздемьная функция почки, сцинтиграфия.

Контактный автор: Юрова М.B, iurovamv@gmail.com.

For citation: Alyaev Yu.G., Khokhlachev S.B., Fiev D.N., Borisov V.V., Proskura A.V., Yurova M.V. A new approach for split renal function evaluation of glomerular filtration rate, perfusion and plasma flow by numerical analysis of 3D MSCT-based models. REJR 2018; 8(2):105-109. DOI:10.21569/2222-7415-2018-8-2-105-109.

\section{Статья получена: $\quad$ 23.03.2018 $\quad$ Статья принята: $\quad \mathbf{1 6 . 0 5 . 2 0 1 8}$}

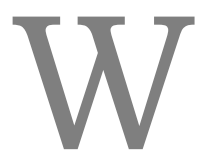

ith respect to providing comprehensive and accurate information about tumor size and shape in relation to the kidney and adjacent organs and tissues, contrast-enhanced multi-slice computed tomography (MSCT) has become a commonly used imaging modality in urology. Modern MSCT scanners allow for performing a three-dimensional (3D) rendering of a region of interest and thus leading to well-balanced decision-making in advanced renal tumor. The evaluation of split renal function is traditionally based on renal scintigraphy data (RS). RS with technetium-99m MAG3 is utilized to measure kidney function. Injection of a radioactive tracer is followed at 2 minutes by measurement of the amount of decay from each kidney. It is a researcher-dependent way of split kidney function assessment. As well as that results of RS may depend on patient's weight and patient's body movements during the procedure [2, 7]. However, it is commonly used in the clinical settings [4, 5, 8].

Contrast-enhanced MSCT is a 4-phase investigation providing a series of images in nonenhanced, arterial, venous, and excretory modes. Modern MSCT scanners allow for performing a $3 \mathrm{D}$-reconstruction of a ROI in every phase. Presumably, fusion of all the phases into a 3D-image would facilitate better understanding and interpretation of the preoperative imaging data and lead to a carefully-weighted decision-making in advanced renal tumor [9]. Images are reconstruct- ed with a $1 \mathrm{~mm}$-slice thickness in multiple planes. An Amira Version 5.4. (Konrad-Zuse-Zentrum, Berlin) software was used to generate 3D CTmodels [6]. As it was demonstrated in the previous papers utilizing Amira software may aid for decision-making leading to less operative time, blood loss, warm ischemia time, length of hospital stay and negative surgical margins [1, 3]. Currently, Amira is routinely used in a Research Institute for Uronephrology and Reproductive Health for preoperative decision-making. However, we aim to present data on Amira for split renal function assessment.

Objective.

This paper aims to present how numerical analysis of kidney 3D-models can be used to evaluate split renal function.

Materials and Methods.

From November, 2015 to May, 2017, 88 patients were enrolled into a prospective study launched in a Research Institute for Uronephrology and Reproductive Health. Inclusion criteria were as follows: 1) patients wirh urological diseases leading to kidney function loss; 2) availability of contrast-enhanced MSCT and renal scintigraphy clinical data. Exclusion criteria: voluntary abandonment from further work-up or no available clinical data at a three months follow-up. The mean age of patients was 58 years (CI \pm 21.7 ). 3200-4200 Hounsefield unit (HU) radiopaque agents were used to perform MSCT. Algebraic determination of split renal function was performed 
with Amira Version 5.4. software (licence number ASTND.44644). An IT-specialist was blinded to the results of RS.

MSCT data was copmared to RS and histopathological findings Statistical analysis of data obtained was performed using MedCalc Statistical Software version 17.0.4 (MedCalc Software bvba, Ostend, Belgium; 2017).

\section{Results.}

4.1. Mathematical analysis of 3D-models generated from contrast-enhanced multi-slice computed tomography (MSCT) scans. Four-phase abdominal CT-images included non-enhanced, arterial, venous, and excretory phase data sets. The following protocol was established: 1) precontrast scans (t_1); 2) arterial scans (shortly after a contrast reaches the renal arteries); 3) paren-

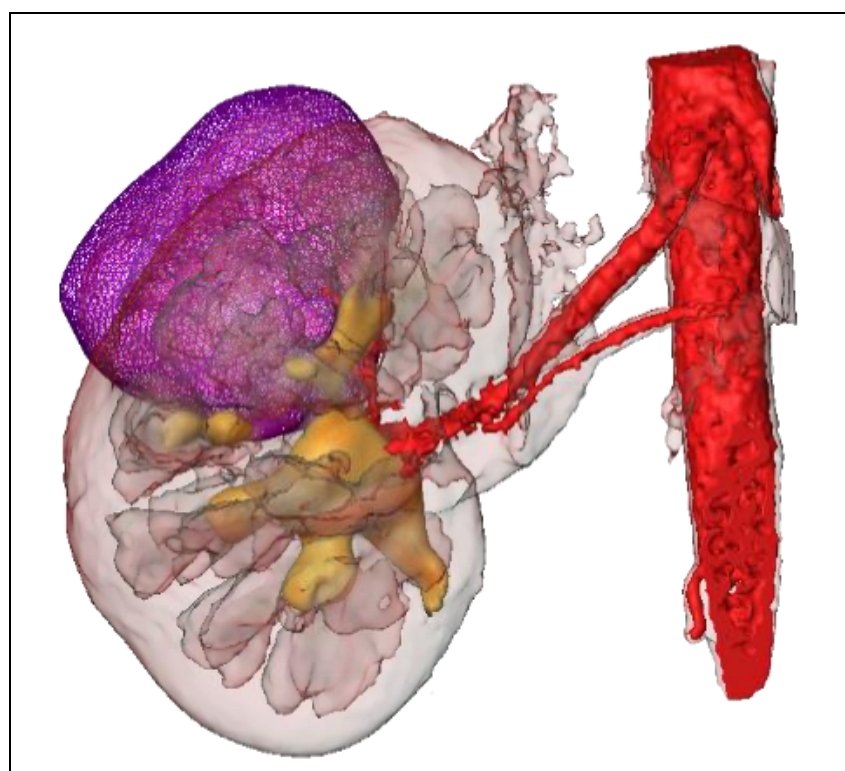

Fig. 1 (Рис. 1)

\section{Fig. 1. 3D-model of MSCT.}

Regions of interest with high attenuation are made transparent. Lesion is outlined and "substracted" from the model.

\section{Рис. 1. 3D-модель MCKT.}

Дия зон интереса использован фильтр прозрачности. Объем опухолевой ткани изъят из объема, к которому будут применены параметры расчета фрнкции паренхимы.

chymal scans (50 to 60 seconds after the arterial phase); 4) excretory scans (seven minutes after the arterial phase). Images were collected in a DICOMformat. Original images are mispresented for further analysis due to "white noise" distortion (noise containing many frequencies with equal intensities). Application of various filters allow for better image quality acquisition.

Amira 5.4.5 software tools allow freeing the margins of the kidney from adjacent organs with similar attenuation. Structures with different attenuation values can be "added" to or "subtracted" from the model. Figure 1 shows kidney cyst (upper pole) and a kidney lesion (lower pole). Cysts do not accumulate contrast agent so they do not affect numerical analysis.

However, kidney lesions being highly vascularized need to be subtracted from the 3D-model (1) by estimating radiological density of a contrast agent $\mathrm{n}\left(\mathrm{x}, \mathrm{t} \_\mathrm{i}\right)$ at $\mathrm{a} \mathrm{t} \_\mathrm{i}$ time:

$n\left(x, t_{i}\right)=-1000 * 1$ (inside the lesion) $+n\left(x, t_{i}\right) * 1$ (outside the lesion),

Regions of interest with high attenuation and regions with plenty of contrast agent (veins and arteries) are "substracted". Crust relative contrast flows are compared in the left (L) and right (R) kidney (2).

Plasma flow $(R)=\frac{100 * M_{\operatorname{cortex}(R)}}{M_{\operatorname{cortex}(R)}+M_{\operatorname{cortex}(L)}}$, Plasma flow $(L)=\frac{100 * M_{\operatorname{cortex}(L)}}{M_{\operatorname{cortex}(R)}+M_{\operatorname{cortex}(L)}}$

where

Plasma flow - percent of the contrast agent into the cortex;

$M$ - 〈mass $\rangle$ of contrast agent in a selected volume of right or left kidney cortex $\left(\mathrm{Hu}^{*} \mathrm{~cm}^{3}\right)$

50-60 seconds ( $t$-2) after the arterial phase another scan is performed. Contrast agent delivered to the cones $\left(\Delta M_{\text {urine } 1(2)}\right)$ of the kidney is assessed (3):

$$
\Delta M_{\text {urine } 1(2)}=\sum_{\boldsymbol{x} \text { in (cones) }} \Delta n_{\text {urine } 1}\left(\boldsymbol{x}, t_{2}\right) * \Delta V \text {. }
$$

Seven minutes after the arterial phase another scan is performed (t_3) - excretory phase. Secondary urine formation can be estimated in this phase. However, due to the fact that urine from each kidney is mixed in the bladder total contrast agent release can be assessed.

"Label Voxel" mode is used to outline region of contrast agent distribution. An important characteristic of kidney function is an ability of the renal cortex (nephrons) to produce urine. This value (U_tot) can be calculated (4) by dividing the volume of radiopaque agent excreted by the 7 th minutes by the volume (V_cortex) of the cortical layer of the parenchyma $(\mathrm{P})$ :

$$
U_{\text {tot }(R \text { or } L)}=\operatorname{tot} * P_{(R \text { or } L)} / V_{\text {plasma }(R \text { or } L)}
$$

Where tot characterizes the excretory function of the kidneys (\%). If a patient has stones in the pyelocaliceal system, then their "mass" in $\mathrm{HU}$ must be subtracted from the mass that we obtained earlier, adding $n\left(x, t \_3\right)$ over the selected area in order to obtain the "mass" of contrast agent brought with secondary urine. Separately calculating the masses of contrast agent, we find the distribution of contrast agent in the secondary urine on the left and on the right (5):

$$
\text { Perfusion }_{R}=\frac{\mathrm{M}_{R}}{\mathrm{M}_{L}+\mathrm{M}_{R}} \text {, Perfusion }{ }_{L}=\frac{\mathrm{M}_{L}{ }^{-}}{\mathrm{M}_{L}+\mathrm{M}_{R}} \text {. }
$$

However, it is quite rare that the contrast agent filtered by both kidneys reaches the bladder at a different time and rate (e.g.: unilateral obstruction of the upper urinary tract). From the en- 


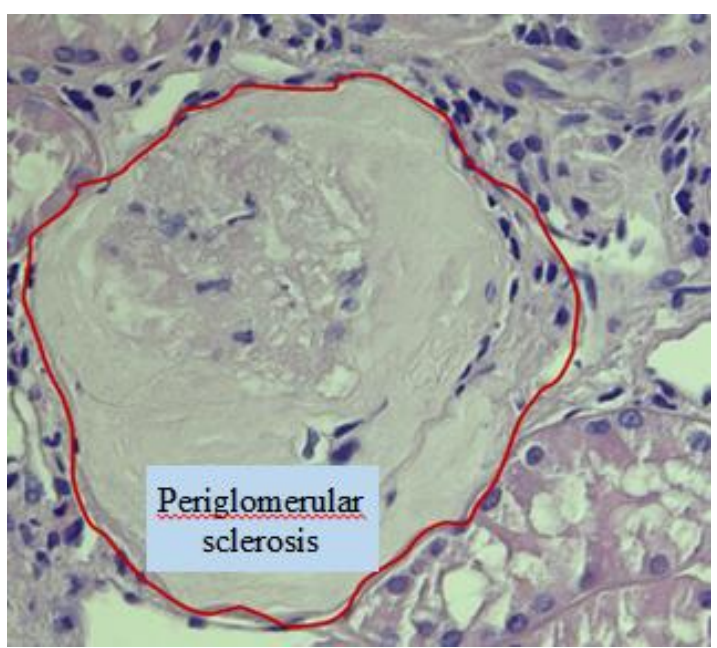

Fig. 2 (Рис. 2)

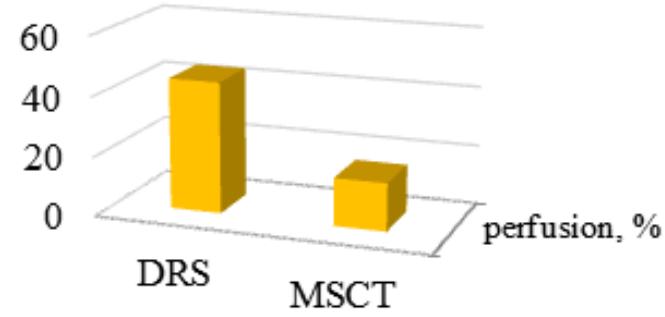

\begin{tabular}{l|c|c}
\cline { 2 - 3 } & DRS & MSCT \\
\hline a perfusion, $\%$ & 44 & 16 \\
\hline
\end{tabular}

Fig. 3 (Рис. 3)
Fig. 2. Light microscopy (x 400).

Shrunk kidney glomerulus (encircled with the red line) with large Bowman's space. Hematoxylin \& eosin stain.

\section{Рис. 2. Световая микроскопия (х 400).}

Склерозированные клубочки (обведены по контуру красной $\Lambda$ иией) с расширенным пространства Боумена. Окрашивание гематоксилином и эозином.

tire flow of contrast agent, part of it enters the urinary tract and another one goes back to the veins. Coefficient $\mathrm{K} \_2,3$ helps to assess the distribution of contrast agent flows to the kidney and to the veins (6). This coefficient can be estimated by dividing the amount of contrast agent in the entire parenchyma in the venous phase (the moment when contrast agent passed the renal arteries and reached the nephrons) by the amount of the contrast agent of this kidney in the excretory phase:

$$
K_{2,3}=M_{\text {parenchyma(2) }} / M_{\text {urine_2(3). }} \text {. }
$$

By the value of $\mathrm{K} \_2,3$, one can judge the division of the total flow of contrast agent between blood supply systems and urine formation. For the reference value, we calculated the coefficient $\mathrm{K} \_2,3$ in a healthy 21 -year-old volunteer with 100 $\mathrm{ml}$ of contrast agent at a rate of four $\mathrm{ml} / \mathrm{sec}$ $\approx 0.7$.

One of the most important indicator of the renal function, - glomerular filtration rate, - was also calculated (7):

$$
\text { Glomerular Filtration }=\sum_{x \text { in } \Omega}\left[n_{(x, t i)}-n_{(x, t)}\right] * \Delta V_{\text {lattice }}
$$

general, the described approach makes it possible to judge the segmentary function of the kidneys.

4.2. Renal scintigraphy (RS). In addition to the technique based on the assessment MSCT kidney data with contrast, in this research work
Fig. 3. Data RS and MSCT with numerical processing of data on the functional ability of the kidney.

Orbital bone borders were marked on every axial slice.

Рис. 3. Аанные реносцинтиграфии (РС) и МСКТ с отображением функциональной сохранности паренхимы в численном эквиваленте.

we compared the renal function obtained by RS. The results were analyzed, - a statistically significant correlation between two methods of split renal function assessment was observed. Comparison of data on perfusion of the right and left kidneys obtained with RS and MSCT shows the following results: $\mathrm{P}<0,004$ and $\mathrm{P}<0,0001$ accordingly.

4.3. Histopathological data. When studying the structures of the renal parenchyma via microscopy, changes were revealed. In patients with hydronephrosis, pathomorphological data indicated a significantly reduced functional ability of the kidney tissue (fig. 2), which is more correlated with the results of the mathematical analysis of MSCT kidney data with contrast than with data from RS (fig. 3).

Conclusion.

A new approach for split renal function assessment of glomerular filtration rate, perfusion and plasma flow by numerical analysis of $3 \mathrm{D}$ MSCT-based models allows for both acquiring detailed data on clinical anatomy and evaluation of renal function. As far, as we aimed to present data on new method, we can conclude that it is as accurate as RS. Besides it is characterized by statistically proved advantage over the last in assessing the functional state of the kidney parenchyma when it is compromised in conditions of permanent retentional compression caused by hydro- 


\section{RUSSIAN ELECTRONIC JOURNAL OF RADIOLOGY}

nephrosis. Thus, a new approach is not only the way to assess glomerular filtration rate, perfusion and plasma flow, but it is also an improved method for decision-making and more accurately selection the amount of intervention with tendency to be optimally appropriate for each patient personally.

\section{References:}

1. El-Diastya M. T., Gaballab G., Gadc H. M., Borgb M. A., AbouElgharc M. E., Sheirc K. Z., Diastyc T.A. Evaluation of CT perfusion parameters for assessment of split renal function in healthy donors. The Egyptian Journal of Radiology and Nuclear Medicine. 2016; 47 (4): 1681-88.

2. Lin K.J., Huang J.Y., Chen Y.S. Fully Automatic Region of Interest Selection in Glomerular Filtration Rate Estimation from 99mTc-DTPA Renogram. Journal of Digital Imaging. 2011; 24 (6): 1010-23.

3. Glybochko P.V., Aljaev Ju.G., Bezrukov E.A., Sirota E.S., Proskura A.V. 3d-technologies as a core element of planning and implementation of virtual and actual renal surgery. Urology. 2015; 4: 117-120 (in Russian).

4. Wesolowski C. A., Wanasundara S. N., Wesolowski M.J., Erbas B., Babyn P.S. J Nucl Med Mol Imaging. 2016; 43: 550.

5. Nilsson H., Wadström J., Andersson L.G., Raland H. and Magnusson A. Measuring split renal function in renal donors: can computed tomography replace renography? Acta Radiologica. 45 (4): $474-480$
Источник финансирования и конфмикт интересов.

Авторы данной статьи подтвердили отсутствие финансовой поддержки исследования и конфликта интересов, о которых необходимо сообщить.

6. Alyaev Yu. G. et al. 3D technology for kidney surgery: from virtual to real surgery (ed Glybochko P.V. and Alyaev Yu.G. M.: GEOTAR, 2014. 5-280 p. (in Russian).

7. Veenboer P. W., Hobbelink M. G. G., Ruud Bosch J. L. H., Dik P., van Asbeck F. W. A., Beek F. J. A. and de Kort. Diagnostic accuracy of Tc-99m DMSA scintigraphy and renal ultrasonography for detecting renal scarring and relative function in patients with spinal dysraphism. Neurourol Urodynam. 2015; 34: 513518.

8. Kumar K., Ahmad A., Kumar S., Choudhry V., Kumar R., Singh T. M. and Muzaffar M. A. Evaluation of renal histopathological changes, as a predictor of recoverability of renal function following pyeloplasty for ureteropelvic junction obstruction. Nephro Urol Mon. 2015; 7 (4): e28051.

9. Torimoto I., Takebayashi S., Sekikawa Z., Teranishi J., Uchida K. and Inoue T. Renal perfusional cortex volume for arterial input function measured by semiautomatic segmentation technique using MDCT angiographic data with 0.5-mm collimation AJR. Am J Roentgenol. 2015; 204 (1): 98-104. 